\title{
Pengaruh Perilaku Usaha dan Pemasaran terhadap Keputusan Pembelian pada PT Mulya Krida Resik Medan
}

\author{
*Irvan Rolyesh Situmorang ${ }^{1}$, Suwandi ${ }^{2}$, \\ ${ }^{123}$ STIE Eka Prasetya, Indonesia \\ *(Email: Irvanrolyesh@ymail.com )
}

\begin{abstract}
This study aims to determine the effect of Business Behavior and Marketing on Purchasing Decisions at PT Mulya Krida Resik Medan. The research methodology used is quantitative descriptive method. The type of data used in this study is quantitative data, which is obtained in the form of numbers and numbers. Sources of data in the form of primary data and secondary data. Primary data were obtained from distributing questionnaires, secondary data were obtained from companies, journals and books relating to Business Conduct and Marketing and Purchasing Decisions. The population in this study amounted to 176 customers and the sample in this study amounted to 122 customers. Data analysis uses multiple linear regression analysis methods. There is a positive and significant influence between Business Conduct and Marketing on Purchasing Decisions at PT Mulya Krida Resik.
\end{abstract}

Keywords: Business Behavior; Marketing; Purchasing Decisions

\begin{abstract}
ABSTRAK
Penelitian ini bertujuan untuk mengetahui pengaruh Perilaku Usaha dan Pemasaran terhadap Keputusan Pembelian pada PT Mulya Krida Resik Medan. Metodologi penelitian yang digunakan adalah metode deskripstif kuantitatif. Jenis data yang digunakan dalam penelitian ini adalah data kuantitatif, yaitu yang diperoleh dalam bentuk angka dan bilangan. Sumber data berupa data primer dan data sekunder. Data primer diperoleh dari penyebaran kuesioner, data sekunder diperoleh dari perusahaan, jurnal dan buku-buku yang berkaitan dengan Perilaku Usaha dan Pemasaran serta Keputusan Pembelian. Populasi dalam penelitian ini berjumlah 176 pelanggan dan sampel dalam penelitian ini berjumlah 122 pelanggan. Data analisis mengunakan metode analisis regresi linear berganda. Terdapat pengaruh positif dan signifikan antara Perilaku Usaha dan Pemasaran terhadap Keputusan Pembelian pada PT Mulya Krida Resik.
\end{abstract}

\section{Kata Kunci : Perilaku Usaha; Pemasaran; Keputusan Pembelian}

\section{PENDAHULUAN}

PT Mulya Krida Resik merupakan perusahaan yang berdiri sejak tahun 2000 sebagai distributor tinta percetakan. Beberapa produk tinta flexo, offset dan gravur. PT Mulya Krida Resik dikenal sebagai pakar di bidang isi ulang tinta inkjet, toner dan ribbon. Karena selain didukung dengan tenagatenaga ahli yang berpengalaman serta selalu menggunakan material premium untuk menghasilkan produk-produk dengan kualitas premium. Berdasarkan survey awal bahwa terdapat keputusan pembelian tinta percetakan pada perusahaan ini sedang mengalami penurunan yang dapat dilihat dari penurunan penjualan.

Menurut Sanusi (2014:42), Perilaku Usaha adalah suatu nilai yang diwujudkan dalam perilaku yang dijadikan sumber daya, tenaga penggerak, tujuan, siasat, kiat, proses, dan hasil bisnis. Berwirausaha merupakan salah satu cara seseorang untuk bekerja dan menitih karir untuk kehidupan mereka di masa yang akan datang. Dengan berwirausaha dapat pula 
membukakan lapangan pekerjaan baru bagi orang-orang yang membutuhkan atau sedang mencari sebuah pekerjaan. Untuk memulai langkah menjadi seorang wirausahawan, individu tersebut harus berani mengambil resiko dan memiliki keyakinan dengan usaha yang akan diambil. Karena dalam dunia bisnis, intensi berwirausaha dan keyakinan akan kemampuan diri adalah kunci untuk menjadikan usaha tersebut sukses atau akan menurun. Ketika seseorang terjun kedalam dunia wirausaha maupun berorganisasi komitmen selaku pemilik dan karyawan sangat penting bagi kemajuan usaha itu sendiri, tanpa komitmen yang pasti mereka tidak akan mampu mempertahankan apa yang dimiliki pada saat tertimpa masalah.

Perilaku usaha PT Mulya Krida Resik masih belum baik disebabkan komitmen perusahaan dengan pelanggan masih belum terpenuhi dengan baik sehingga memicu para pelanggan melakukan keluhan dan menyebabkan tingkat kepercayaan kepada perusahaan semakin menurun. Keluhan yang dilakukan pelanggan kepada perusahaan. Keluhan berupa seringnya harga tidak sesuai dengan kesepakatan seperti saat pelanggan melakukan pemesanan dan deal harga kemudian unit yang dipesan tapi pada saat tanda terima di antar oleh staf sales ke lokasi pelanggan terjadi perbedaan harga yang ditetapkan dimana terdapat selisih harga yang jauh dari kesepakatan, pengiriman juga sering tidak sesuai dengan apa yang dijanjikan, penurunan kualitas produk tinta dimana tidak terlalu hitam dalam pengunaannya sehingga memicu kerugian pelanggan dalam pengunaan tinta. Hal ini mencerminkan perilaku usaha perusahaan ini masih belum optimal bagi pelanggan.

Menurut Assauri (2014:168), Pemasaran pada dasarnya adalah rencana yang menyeluruh, terpadu dan menyatu di bidang pemasaran, yang memberikan paduan tentang kegiatan yang akan dijalankan untuk dapat tercapainya tujuan pemasaran suatu perusahaan. Penting bagi perusahaan untuk mengatahui strategi pemasaran yang tepat dan sesuai untuk produk yang akan dijual di pasaran. Dengan strategi pemasaran tepat dan sesuai maka produk akan mudah diterima calon konsumen sehingga calon konsumen membeli produk yang akan dijual. Selain strategi pemasaran perusahaan perlu mengetahui posisi produk yang dijual. Posisi disini menunjukkan perbandingan mengenai pangsa pasar dan pertumbuhan pasar dari para pesaingan produk yang sejenis dari perusahaan lain.

Keberhasilan perusahaan dalam memasarkan produk-produk sangat tergantung pada kiat-kiat dan strategi pemasaran yang dilakukan karena dengan penerapan strategi pemasaran yang tepat, perusahaan dapat menciptakan dan memelihara serta mengembangkan permintaan konsumen secara menyakinkan dan berkesinambungan. Apabila omset penjualan mengalami peningkatan yang lambat, maka harus dianalisis apakah hal tersebut disebabkan oleh kurang efektifnya strategi pemasaran yang dilakukan atau mungkin di pengaruhi oleh selera dan perilaku konsumen yang sudah berubah.

Pemasaran yang sudah PT Mulya Krida Resik dilakukan selama ini adalah menggunakan media online dengan promosi melalui instagram dan personal selling yaitu penjualan langsung berinteraksi menawarkan produk dan saling bertemu tatap muka dengan calon pembeli. Staf personal selling atau staf salesman melakukan promosi ke lokasi pelanggan, mengantar tanda terima dan melakukan penagihan sesuai jadwal yang ditetntukan oleh perusahaan. Selama proses menawarkan produk itu penjual menjelaskan jenis produk, kegunaan produk, harga produk dan keunggulan produk. Lokasi PT Mulya Krida Resik masih tergolong sulit untuk ditemukan karena berada di area yang tidak begitu besar. Promosi 
berupa pemberian hadiah yang belum menarik dan paket hadiah yang cukup tinggi belum sesuai dengan potongan harga yang diberikan kepada pelanggan. Lokasi PT Mulya Krida Resik masih tergolong sulit untuk ditemukan karena berada di area yang tidak begitu besar.

Berdasarkan uraian latar belakang diatas tersebut, maka peneliti tertarik untuk memilih "Pengaruh Perilaku Usaha dan Pemasaran terhadap Keputusan Pembelian pada PT Mulya Krida Resik Medan"

\section{Tujuan Penelitian}

Berdasarkan perumusan masalah tersebut, penelitian ini dilakukan dengan tujuan ialah

1. Untuk mengetahui pengaruh Perilaku Usaha terhadap Keputusan Pembelian pada PT Mulya Krida Resik.

2. Untuk mengetahui pengaruh Pemasaran terhadap Keputusan Pembelian pada PT Mulya Krida Resik.

3. Untuk mengetahui pengaruh Perilaku Usaha dan Pemasaran terhadap Keputusan Pembelian pada PT Mulya Krida Resik.

\section{KAJIAN LITERATUR}

\subsection{Keputusan Pembelian}

Keputusan Pembelian Konsumen merupakan sebuah tindakan yang dilakukan konsumen untuk membeli suatu produk. Setiap produsen pasti menjalankan berbagai strategi agar konsumen memutuskan untuk membeli produknya.

Menurut Sunyoto (2014:281), “Keputusan Pembelian merupakan tahap evaluasi berakibat bahwa konsumen membentuk preferensi diantara alternative-alternative merek barang."

Menurut Hasan (2013:133), “Keputusan Pembelian ulang merupakan prilaku yang muncul sebagai respons terhadap objek yang menunjukkan keinginan pelanggan untuk melakukan pembelian ulang sebagai tahapan penting dari loyalitas konsumen dalam bentuk komitmen terhadap produk jasa terpilih secara konsisten di masa yang akan datang, meskipun pengaruh situasi dan usaha pemasaran mempunyai potensi untuk menyebabkan perubahan perilaku.."

Menurut Setiadi (2016:17), "Pengambilan keputusan konsumen (consumerdecision making) adalah konsumen membentuk preferensi terhadap merek-merek yang terdapat pada perangkat pilihan."

Menurut Manap (2016:250), "Keputusan Pembelian adalah tahap yang harus diambil setelah melalui tahapan evaluasi alternatif. Bila konsumen mengambil keputusan, maka ia akan mempunyai serangkaian keputusan menyangkut jenis produk, merek, kualitas, model, waktu, harga, cara pembayaran dan sebagainya."

Menurut Simamora (2013:81), "Keputusan Pembelian adalah perilaku konsumen yang menyangkut suatu proses keputusan sebelum pembelian serta tindakan dalam memperoleh, memakai. mengkonsumsi dan menghabiskan produk."

Berdasarkan pengertian diatas dapat disimpulkan bahwa keputusan pembelian 
merupakan suatu proses penyelesaian masalah yang terdiri dari menganalisa atau pengenalan kebutuhan dan keinginan, pencarian informasi, penilaian sumber-sumber seleksi terhadap alternatif pembelian, keputusan pembelian, dan perilaku setelah pembelian.

\subsection{Perilaku Usaha}

Wirausaha yang mempunyai kemampuan, melihat dan menilai kesempatan bisnis, mengumpulkan sumber-sumber daya yang dibutuhkan guna mengambil keuntungan daripadanya serta mengambil tindakan yang tepat.

Menurut Sunyoto (2014:1), "Perilaku Usaha adalah Semangat, sikap perilaku dan kemampuan seseorang dalam menangani usaha atau kegaitan yang mengarahkan pada upaya cara kerja, teknologi dan produk baru dengan meningkatkan efisiensi dalam rangka memberikan pelayanan yang lebih baik dan keuntungan lebih besar."

Menurut Sanusi (2014:42), "Perilaku Usaha adalah suatu nilai yang diwujudkan dalam perilaku yang dijadikan sumber daya, tenaga penggerak, tujuan, siasat, kiat, proses, dan hasil bisnis."

Menurut Sudomo (2013:21), "Perilaku Usaha adalah segala sesuatu yang penting mengenai seorang wirausaha, yakni orang yang memiliki sifat bekerja keras dan berkorban, memusatkan segala daya dan berani mengambil risiko untuk mewujudkan gagasannya."

Menurut Yanti (2015:18), "Perilaku Usaha adalah suatu fungsi dari interaksi antara seorang individu dengan lingkungannya. Hal ini berarti bahwa seorang individu dengan lingkungan keduannya secara langsung akan menentukan perilaku seseorang yang bersangkutan."

Menurut Yuyus (2011:29), "Wirausaha (entrepreneur) adlaah mereka yang mendirikan, mengelola dan mengembangkan dan melembagakan perusahaan miliknya sendiri."

Berdasarkan teori di atas bahwa perilaku usaha adalah segala sesuatu yang penting mengenai seorang wirausaha yang berkaitan dengan tindakan dan sifat seseorang dalam menjalankan dan manfaatkan segala potensi yang di.

\subsection{Pemasaran}

Setiap perusahaan selalu melaksanakan operasional aktivitasnya, yang didahului dengan membuat rencana, bagi kelangsungan dan pertumbuhan jangka panjang, yang didasarkan pada situasi, peluang, tujuan dan sumber dayanya.

Menurut Abdurrahman (2015:2), "Pemasaran adalah suatu sistem total dari kegiatan bahwa yang dirancang untuk merencanakan, menentukan harga, promosi, mendistribusikan barang-barnag yang dapat memuaskana keinginan dan mencapai pasar sasaran serta tujuan perusahaan."

Menurut Assauri (2014:168), "Pemasaran pada dasarnya adalah rencana yang menyeluruh, terpadu dan menyatu di bidang pemasaran, yang memberikan paduan tentang kegiatan yang akan dijalankan untuk dapat tercapainya tujuan pemasaran suatu perusahaan."

Menurut Nitisusastro (2013:13), "Pemasaran merupakan pola langkah dan pola pikir yang harus dijalankan dan atau harus tidak dijalankan di masa yang akan datang, setidaknya 
dalam kurun waktu tertentu."

Menurut Firmansyah (2019:2), "Pemasaran adalah mengidentifikasi dan memenuhi kebutuhan manusia dan sosial."

Menurut Darmanto (2016:5), "Pemsaran adalah merupakan proses dariseseorang atau organisasi untuk mempenagruhi orang lain atau organsiasi lain agar merek yang menginginkan dan memerlukan produk atau jasa dapat terpenuhi dan merek yang memiliki produk atau jasa dapat keuntungan ."

Berdasarkan pengertian di atas, strategi pemasaran merupakan suatu rencana yang menyeluruh dan menjabarkan ekspektasi perusahaan di bidang pemasaran yang memberikan paduan untuk kegiatan program pemasaran yang bertujuan untuk mencapai tujuan pemasaran perusahaan.

Berdasarkan uraian diatas dapat disimpulkan bahwa kerangka pemikiran adalah sebagai berikut:

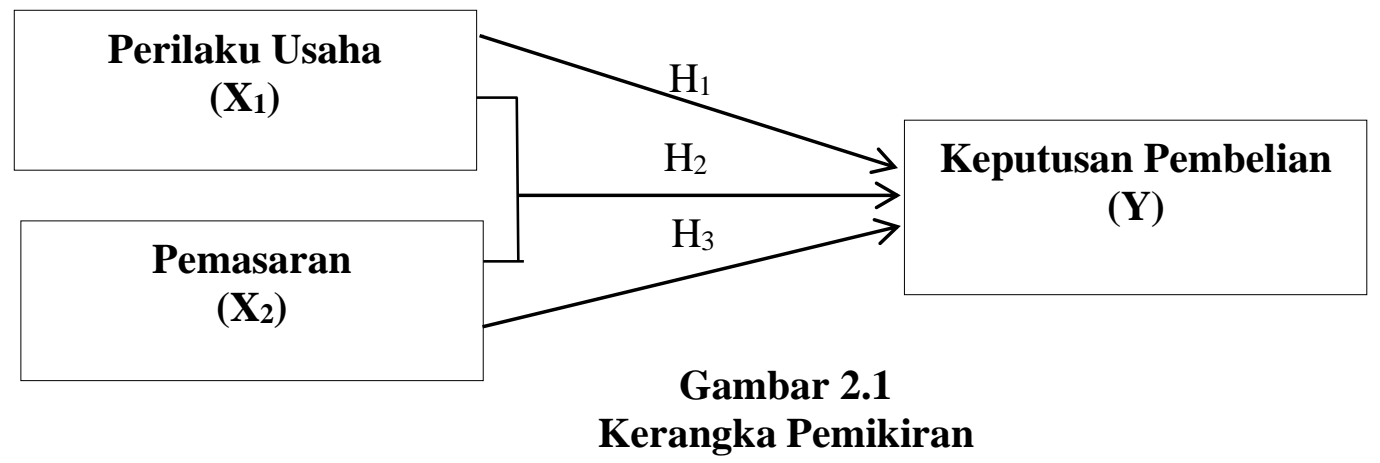

\section{METODE PENELITIAN}

Jenis data yang digunakan dalam penelitian ini terdiri dari data kuantitatif dan kualitatif. Sumber data yang digunakan dalam penelitian ini adalah data primer dan sekunder. Peneliti mengambil populasi dalam penelitian ini sebanyak 176 pelanggan. Jumlah sampel dalam penelitian ini adalah sebanyak 122 pelanggan. Teknik sampling yang digunakan adalah simple random sampling. Teknik pengumpulan data yang digunakan dalam penelitian ini meliputi studi pustaka, wawancara dan interview. 
Table 1. Definisi Operasional dan Pengukuran Variabel

\begin{tabular}{|c|c|c|c|}
\hline Variabel & Defenisi & Indikator & $\begin{array}{c}\text { Skala } \\
\text { Pengukuran }\end{array}$ \\
\hline $\begin{array}{l}\text { Perilaku Usaha } \\
\text { (X1) }\end{array}$ & $\begin{array}{l}\text { Semangat, sikap perilaku dan } \\
\text { kemampuan seseorang dalam } \\
\text { menangani usaha atau kegaitan } \\
\text { yang mengarahkan pada upaya cara } \\
\text { kerja, teknologi dan produk baru } \\
\text { dengan meningkatkan efisiensi } \\
\text { dalam rangka memberikan } \\
\text { pelayanan yang lebih baik dan } \\
\text { keuntungan lebih besar. }\end{array}$ & $\begin{array}{l}\text { 1. Pasar potensial yang } \\
\text { menguntungkan } \\
\text { 2. Mengetahui perilaku } \\
\text { konsumen } \\
\text { 3. Strategi pemasaran } \\
\text { 4. Perencanaan pasar } \\
\text { sasaran yang nyata } \\
\text { 5. Memprediksi pasar } \\
\text { dimasa yang akan } \\
\text { datang }\end{array}$ & Skala Likert \\
\hline & Sumber : Sunyoto $(2014: 1)$ & $\begin{array}{l}\text { Sumber : Sunyoto } \\
(2014: 89)\end{array}$ & \\
\hline $\begin{array}{l}\text { Pemasaran } \\
\text { (X2) }\end{array}$ & $\begin{array}{l}\text { Pemasaran adalah suatu sistem } \\
\text { total dari kegiatan bahwa yang } \\
\text { dirancang untuk merencanakan, } \\
\text { menentukan harga, promosi, } \\
\text { mendistribusikan barang-barnag } \\
\text { yang dapat memuaskana keinginan } \\
\text { dan mencapai pasar sasaran serta } \\
\text { tujuan perusahaan. }\end{array}$ & $\begin{array}{l}\text { 1. Proses pemasaran } \\
\text { 2. Merancang strategi } \\
\text { pemasaran } \\
\text { 3. Membangun } \\
\text { program pemasaran } \\
\text { 4. Membangung } \\
\text { lingkungan } \\
\text { 5. Nilai pelanggan }\end{array}$ & Skala Likert \\
\hline & Sumber: Abdurrahman (2015:2) & $\begin{array}{l}\text { Sumber : Abdurrahman } \\
(2015: 3)\end{array}$ & \\
\hline \multirow[t]{2}{*}{$\begin{array}{c}\text { Keputusan } \\
\text { Pembelian (Y) }\end{array}$} & $\begin{array}{l}\text { Keputusan Pembelian merupakan } \\
\text { tahap evaluasi berakibat bahwa } \\
\text { konsumen membentuk preferensi } \\
\text { diantara alternative-alternative } \\
\text { merek }\end{array}$ & $\begin{array}{ll}\text { 1. Keputusan tentang } \\
\text { merek } \\
\text { 2. Keputusan tentang } \\
\text { penjualnya } \\
\text { 3. Keputusan tentang } \\
\text { jumlah produk } \\
\text { 4. Keputusan tentang } \\
\text { cara pembavaran }\end{array}$ & \multirow[t]{2}{*}{ Skala Likert } \\
\hline & $(2014: 281)$ & $\begin{array}{l}\text { Sumber } \\
(2014: 283)\end{array} \quad$ Sunyoto & \\
\hline
\end{tabular}

\section{Analisis Regresi Linear Berganda}

Analisis regresi berganda untuk mengetahui pengaruh dua atau lebih variabel bebas $(\mathrm{X} 1,2,3, \ldots, \mathrm{n})$ terhadap variabel terikat $(\mathrm{Y})$. Rumusnya sebagai berikut :

Keterangan :

$$
\mathbf{Y}=\mathbf{a}+\mathbf{b}_{1} \mathbf{X}_{1}+\mathbf{b}_{2} \mathbf{X}_{2}+\mathbf{e}
$$

$\begin{array}{lll}\mathrm{Y} & = & \text { Keputusan Pembelian } \\ \mathrm{X}_{1} & = & \text { Perilaku Usaha } \\ \mathrm{X}_{2} & = & \text { Pemasaran } \\ \mathrm{a} & = & \text { Konstanta } \\ \mathrm{b}_{1}, \mathrm{~b}_{2} & \equiv & \text { Koefisien regresi variabel bebas }\end{array}$




\section{HASIL DAN PEMBAHASAN}

\section{Uji Validitas}

Hasil pengujian validitas untuk variabel bebas dan variabel dalam penelitian ini yaitu sebagai berikut :

Tabel 2. Hasil Uji Validitas

\begin{tabular}{cccccc}
\hline No & $\mathbf{r}_{\text {hitung }}$ & $\mathbf{r}_{\text {hitung }}$ & $\mathbf{r}_{\text {hitung }}$ & $\mathbf{r}_{\text {tabel }}$ & Keterangan \\
\hline 1 & 0,788 & 0,899 & 0,876 & 0,361 & Valid \\
2 & 0,846 & 0,909 & 0,896 & 0,361 & Valid \\
3 & 0,742 & 0,884 & 0,846 & 0,361 & Valid \\
4 & 0,643 & 0,870 & 0,759 & 0,361 & Valid \\
5 & 0,789 & 0,802 & 0,856 & 0,361 & Valid \\
6 & 0,709 & 0,642 & 0,838 & 0,361 & Valid \\
7 & 0,825 & 0,643 & 0,845 & 0,361 & Valid \\
8 & 0,797 & 0,743 & 0,891 & 0,361 & Valid \\
9 & 0,700 & 0,699 & & 0,361 & Valid \\
10 & 0,763 & 0,739 & & 0,361 & Valid
\end{tabular}

Sumber : Hasil Penelitian, 2020 (Data diolah)

Masing-masing pernyataan memililiki nilai $r_{\text {hitung }}>r_{\text {tabel }}(0,361)$ bahwa semua pernyataan atau kuesioner untuk variabel dinyatakan valid.

\section{Uji Reliabilitas}

Berikut hasil pengujian reliabilitas terhadap variabel yang digunakan dalam penelitian yaitu :

Tabel 3.Uji Realibilitas Variabel

\begin{tabular}{lcc}
\hline \multicolumn{1}{c}{ Variabel } & $\begin{array}{c}\text { Jumlah } \\
\text { Pernyataan }\end{array}$ & $\begin{array}{c}\text { Cronbach's } \\
\text { Alpha }\end{array}$ \\
\hline Perilaku Usaha & 10 & 0,918 \\
Pemasaran & 10 & 0,934 \\
Keputusan & 8 & 0,946 \\
Pembelain & & \\
\hline
\end{tabular}

Sumber : Hasil Penelitian, 2020 (Data diolah)

Tabel 3 menunjukan variabel memiliki nilai Cronbach's Alpha sebesar 0,738>0,6 bahwa variabel kuesioner untuk variabel dalam penelitian ini dinyatakan reliabel.

\section{Uji Normalitas}

Berikut ini adalah hasil uji normalitas dengan analisis grafik histogram dan normal $\mathrm{P}$ Plot. 


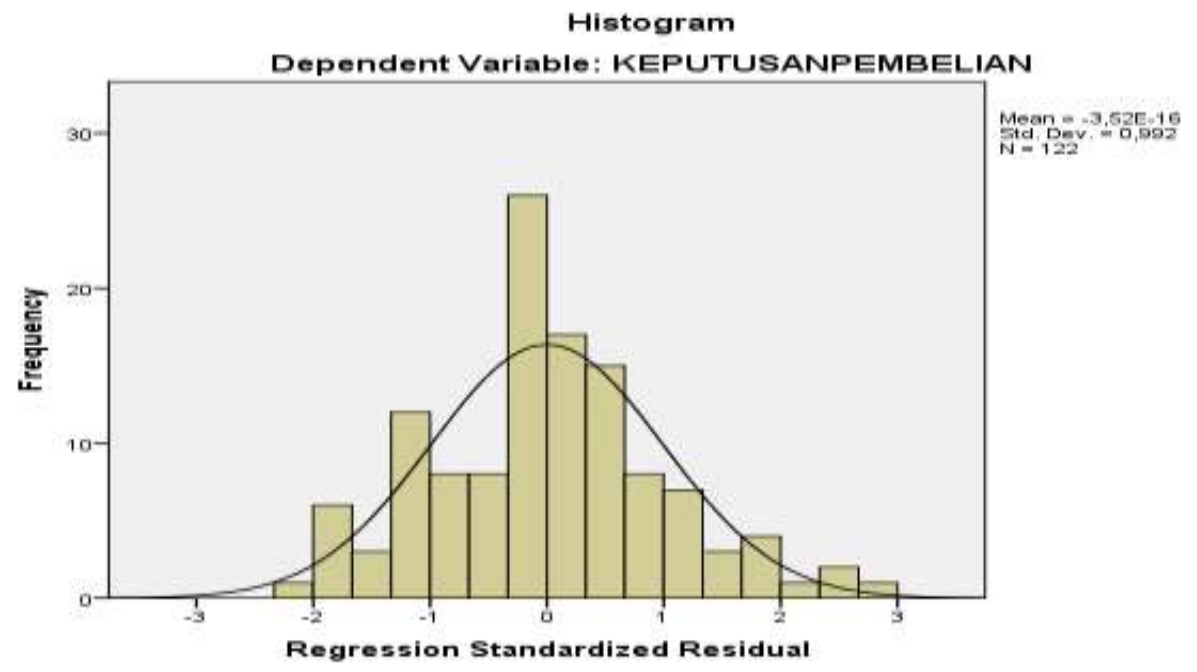

Sumber : Hasil Penelitian, 2020 (Data diolah)

Gambar 1. Grafik Histogram

Gambar 4.2 menunjukkan bahwa grafik histogram mempunyai data riil membentuk garis kurva cenderung simetri tidak melenceng ke kiri atau pun ke kanan, maka dapat dikatakan data berdistribusi normal.

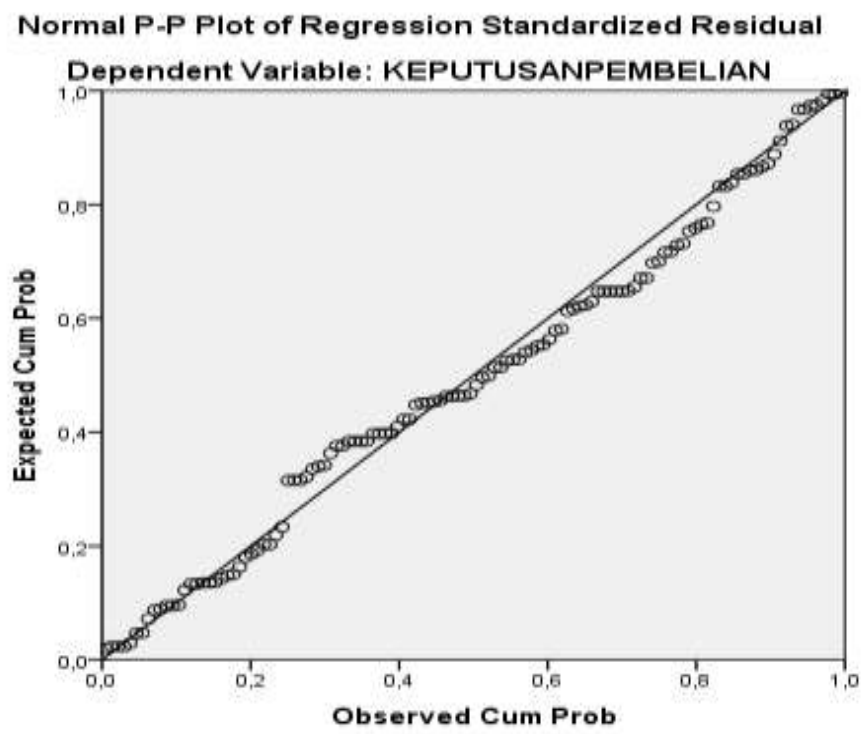

Sumber : Hasil Penelitian, 2020 (Data diolah)

Gambar 2. Grafik Normal Probaility Plot

Gambar 4.3. Grafik Normalitas P-P Plot, terlihat data menyebar di sekitar garis diagonal dan data menyebar sebagian besar mendekati garis diagonal sehingga dapat disimpulkan data berdistribusi normal. 
Hasil uji One Kolmogrov Smirnov dapat dilihat pada tabel 5

Tabel 4 Hasil Uji Normalitas

One-Sample Kolmogorov-Smirnov Test

\begin{tabular}{llr}
\hline & & $\begin{array}{r}\text { Unstandardized } \\
\text { Residual }\end{array}$ \\
\hline $\mathrm{N}$ & Mean & 122 \\
Normal Parameters ${ }^{\mathrm{a}, \mathrm{b}}$ & Std. & DE-7 \\
& Deviation & $631,600,455$ \\
Most Extreme & Absolute &, 068 \\
Differences & Positive &, 065 \\
Kolmogorov-Smirnov Z & Negative &,- 068 \\
Asymp. Sig. (2-tailed) & &, 751 \\
\hline \multicolumn{2}{l}{ a. Test distribution is Normal. } &, 626 \\
\hline \multicolumn{2}{l}{ b. Calculated from data. } &
\end{tabular}

Sumber : Hasil Penelitian, 2020 ( data diolah)

Tabel 5 menunjukkan nilai signifikan yang diperoleh sebesar 0,626>0,05. Dapat disimpulkan bahwa data tersebut menunjukkan data berdistribusi normal.

\section{Uji Multikolinieritas}

Hasil perhitungan multikolinearitas dapat dilihat berikut ini

\section{Tabel 5. Uji Multikolonieritas}

Coefficients $^{\mathrm{a}}$

\begin{tabular}{|c|c|c|c|}
\hline \multicolumn{4}{|c|}{ Coefficients $^{\mathrm{a}}$} \\
\hline \multirow{2}{*}{ Model } & & \multicolumn{2}{|c|}{$\begin{array}{c}\text { Collinearity } \\
\text { Statistics }\end{array}$} \\
\hline & & Tolerance & VIF \\
\hline \multirow{3}{*}{1} & (Constant) & & \\
\hline & $\begin{array}{l}\text { PERILAKU } \\
\text { USAHA }\end{array}$ & ,933 & 1,072 \\
\hline & PEMASARAN & ,933 & 1,072 \\
\hline
\end{tabular}

a. Dependent Variable: KeputusanPembelian

Sumber : Hasil Penelitian, 2020 ( Data diolah )

Tabel 5. menunjukkan masing-masing variabel bebas Perilaku Usaha $\left(\mathrm{X}_{1}\right)$ dan Pemasaran $\left(\mathrm{X}_{2}\right)$ sebesar 0,933 >0,1, sedangkan nilai VIF variabel bebas . menunjukkan masing-masing variabel bebas Perilaku Usaha $\left(\mathrm{X}_{1}\right)$ dan Pemasaran $\left(\mathrm{X}_{2}\right)$ sebesar 1,072<10. Dapat disimpulkan bahwa tidak terjadi multikolinearitas dalam penelitian ini..

\section{Uji Heteroskedastisitas}


Hasil uji heteroskedastisitas dapat dilihat pada gambar 4.4

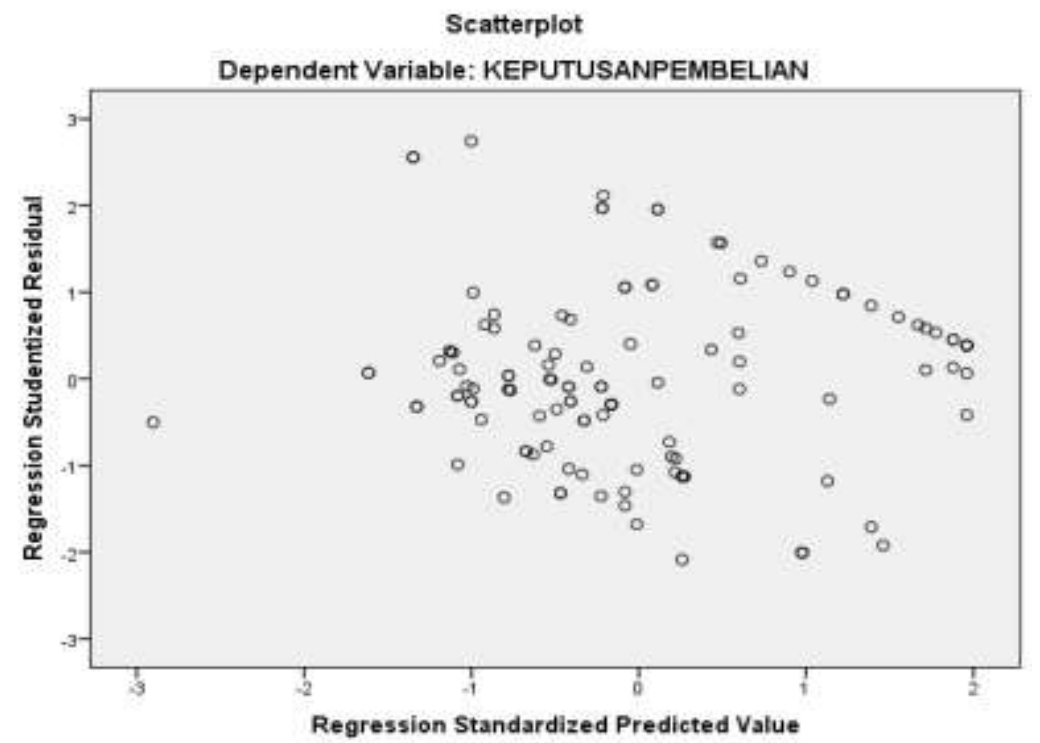

Sumber : Hasil Penelitian, 2020 (Data diolah)

\section{Gambar 3. Grafik Heteroskedastisitas}

Gambar 3. menunjukkan data menyebar dengan pola yang tidak jelas baik di atas maupun di bawah angka nol (0) pada sumbu Y, tidak berkumpul di satu tempat, sehingga dari grafik scatterplot dapat di simpulkan bahwa tidak terjadi heteroskedastisitas pada model regresi dalam penelitian ini.

\section{Analisis Regresi Linear Berganda}

Hasil analisis regresi linear berganda dalam penelitian ini yaitu :

Tabel 6. Hasil Analisis regresi Linear Berganda Coefficients $^{\mathrm{a}}$

\begin{tabular}{|c|c|c|c|c|c|c|c|c|}
\hline \multirow{2}{*}{\multicolumn{2}{|c|}{ Model }} & \multicolumn{2}{|c|}{$\begin{array}{l}\text { Unstandardized } \\
\text { Coefficients }\end{array}$} & \multirow{2}{*}{$\begin{array}{l}\text { Standardized } \\
\text { Coefficients } \\
\text { Beta }\end{array}$} & \multirow[t]{2}{*}{$\mathrm{t}$} & \multirow[t]{2}{*}{ Sig. } & \multicolumn{2}{|c|}{$\begin{array}{c}\text { Collinearity } \\
\text { Statistics }\end{array}$} \\
\hline & & B & $\begin{array}{l}\text { Std. } \\
\text { Error }\end{array}$ & & & & Tolerance & VIF \\
\hline \multirow{3}{*}{1} & (Constant) & 5,389 & 2,734 & & 1,971 & ,051 & & \\
\hline & $\begin{array}{l}\text { PERILAKU } \\
\text { USAHA }\end{array}$ & ,233 &, 066 &, 262 & 3,538 &, 001 & ,933 & 1,072 \\
\hline & PEMASARAN & ,411 &, 061 &, 502 & 6,773 & 000 & ,933 & 1,072 \\
\hline
\end{tabular}




\section{Keputusan Pembelian $=$ 5,389 + 0,233 Perilaku Usaha + 0,411 Pemasaran $+e$}

Makna dari penjelasan analisis regresi linear berganda diatas adalah :

1. Apabila Perilaku Usaha dan Pemasaran tidak mengalami peningkatan atau konstanta maka Keputusan Pembelian sebesar 5,389 satuan.

2. Apabila setiap terjadi peningkatan sebesar satu satuan untuk variabel Perilaku Usaha maka Keputusan Pembelian sebesar 0,233 satuan dengan anggapan variabel Pemasaran tetap.

3. Apabila setiap terjadi peningkatan sebesar satu satuan untuk variabel Pemasaran maka Keputusan Pembelian sebesar 0,411 satuan dengan anggapan variabel Perilaku Usaha tetap.

\section{Uji Signifikan Parsial (Uji t)}

Berikut Tabel hasil pengujian hipotesis secara parsial yaitu :

\section{Tabel 7. Hasil Pengujian Secara Parsial (Uji t)}

\begin{tabular}{|c|c|c|c|c|c|c|}
\hline \multicolumn{7}{|c|}{ Coefficients $^{a}$} \\
\hline \multirow[t]{2}{*}{ Mode } & & \multicolumn{2}{|c|}{$\begin{array}{l}\text { Unstandardized } \\
\text { Coefficients }\end{array}$} & \multirow{2}{*}{$\begin{array}{c}\text { Standardized } \\
\text { Coefficients } \\
\text { Beta }\end{array}$} & \multirow[t]{2}{*}{$\mathrm{t}$} & \multirow[t]{2}{*}{ Sig. } \\
\hline & & B & $\begin{array}{l}\text { Std. } \\
\text { Error }\end{array}$ & & & \\
\hline \multirow{3}{*}{1} & (Constant) & 5,389 & 2,734 & & 1,971 &, 051 \\
\hline & $\begin{array}{l}\text { PERILAKU } \\
\text { USAHA }\end{array}$ & ,233 & ,066 & ,262 & 3,538 &, 001 \\
\hline & PEMASARAN &, 411 & ,061 &, 502 & 6,773 &, 000 \\
\hline
\end{tabular}

a. Dependent Variable: KEPUTUSANPEMBELIAN

Sumber : Hasil Penelitian, 2020 ( Data diolah )

Menunjukkan nilai $t_{\text {tabel }}$ untuk signifikan 0,05 pada derajat bebas $\mathrm{df}=\mathrm{n}-\mathrm{k}$ dimana $\mathrm{k}$ adalah keseluruhan jumlah variabel dan $n$ adalah jumlah sampel maka df $=122-3=119$ adalah sebesar 1,980. Hasil pengujian hipotesis secara parsial (uji t) dapat dijelaskan sebagai berikut:

1. Hasil pengujian hipotesis secara parsial (uji t) diperoleh nilai $t_{\text {hitung }}(3,538)>t_{\text {tabel }}$ $(1,980)$ dan nilai signfiikan sebesar $0,001<0,05$, maka $\mathrm{H}_{1}$ diterima yaitu secara parsial terdapat pengaruh positif dan signifikan antara Perilaku Usaha terhadap Keputusan Pembelian pada PT Mulya Krida Resik.

2. Hasil pengujian hipotesis secara parsial (uji t) diperoleh nilai $t_{\text {hitung }}(6,773)>t_{\text {tabel }}$ $(1,980)$ dan nilai signfiikan sebesar $0,000<0,05$, maka $\mathrm{H}_{2}$ diterima yaitu secara parsial terdapat pengaruh positif dan signifikan antara Pemasaran terhadap Keputusan Pembelian pada PT Mulya Krida Resik.

\section{Uji Signifikan Simultan (Uji F)}

Berikut Tabel hasil pengujian hipotesis secara simultan yaitu :

Tabel 4.8. Hasil Pengujian Secara Simultan (Uji F) 


\begin{tabular}{rlrrrrr}
\multicolumn{7}{c}{ ANOVA $^{\mathrm{a}}$} \\
Model & & $\begin{array}{c}\text { Sum of } \\
\text { Squares }\end{array}$ & \multicolumn{1}{c}{ df } & $\begin{array}{c}\text { Mean } \\
\text { Square }\end{array}$ & F & \multirow{2}{*}{ Sig. } \\
\hline \multirow{4}{*}{1} & Regression & $3,080,456$ & 2 & $1,540,228$ & 37,972 &, $000^{\mathrm{b}}$ \\
& Residual & $4,826,922$ & 119 & 40,562 & & \\
& Total & $7,907,377$ & 121 & & & \\
\hline
\end{tabular}

a. Dependent Variable: KEPUTUSANPEMBELIAN

b. Predictors: (Constant), PEMASARAN, PERILAKUUSAHA

Sumber: Hasil Penelitian, 2020( Data diolah )

Nilai $F_{\text {tabel }}$ pada taraf kepercayaan signifikansi 0,05 pada $\mathrm{df}_{1}=\mathrm{k}-1=3-1=2$ dan $\mathrm{df}_{2}=\mathrm{n}$ $\mathrm{k}=122-3=119$ adalah 3,07. Hasil pengujian hipotesis secara simultan diperoleh nilai $\mathrm{F}_{\text {hitung }}$ $(37,972)>\mathrm{F}_{\text {tabel }}(3,07)$ dengan tingkat signifikansi $0,000<0,05$, maka $\mathrm{H}_{3}$ diterima yaitu secara simultan terdapat pengaruh positif dan signifikan antara Perilaku Usaha dan Pemasaran terhadap Keputusan Pembelian pada PT Mulya Krida Resik.

Koefisien Determinasi $\left(\mathbf{R}^{2}\right)$

Hasil pengujian koefisien determinasi dapat dilihat pada Tabel 8. di bawah ini :

Tabel 4.9 Uji Koefisien Determinasi

\begin{tabular}{|c|c|c|c|c|}
\hline \multicolumn{5}{|c|}{ Model Summary ${ }^{b}$} \\
\hline Model & $\mathrm{R}$ & $\begin{array}{c}\mathrm{R} \\
\text { Square }\end{array}$ & $\begin{array}{l}\text { Adjusted } \\
\text { R } \\
\text { Square }\end{array}$ & $\begin{array}{l}\text { Std. } \\
\text { Error of } \\
\text { the } \\
\text { Estimate }\end{array}$ \\
\hline 1 &, $624^{\mathrm{a}}$ & 390 & ,379 & 6,369 \\
\hline \multicolumn{5}{|c|}{$\begin{array}{l}\text { a. Predictors: (Constant), PEMASARAN, } \\
\text { PERILAKU USAHA } \\
\text { b. Dependent Variable: KEPUTUSAN } \\
\text { PEMBELIAN }\end{array}$} \\
\hline Iasil Pen & an. 202 & (data dio & & \\
\hline
\end{tabular}

Tabel 9. $R$-Square adalah sebesar 0.390 berarti Perilaku Usaha dan Pemasaran dapat menjelaskan Keputusan Pembelian pada PT Mulya Krida Resik sebesar 39\% dan sisanya 61\% dipengaruhi oleh variabel lain di luar dari penelitian ini seperti kualitas pelayanan, atribut produk dan segmentasi.

\section{Pembahasan}

\section{Pengaruh Perilaku Usaha terhadap Keputusan Pembelian pada PT Mulya Krida Resik}

Hasil pengujian hipotesis secara parsial terdapat pengaruh positif dan signifikan antara Perilaku Usaha terhadap Keputusan Pembelian pada PT Mulya Krida Resik.

Hasil Penelitian ini sejalan dengan penelitian yang dilakukan oleh Retno Wijaya (2015) dengan judul Pengaruh Perilaku Usaha dan Pembentukan Brand Awareness terhadap Keputusan Pembelian Motor Suzuki (Studi Kasus di Dealer Tatarunggul Santosa Lodoyo Kecamatan Sutojayan). Hasil penelitian menunjukkan bahwa Perilaku Usaha dan Pembentukan Brand Awareness berpengaruh positif dan signifikan terhadap Keputusan Pembelian Motor Suzuki (Studi Kasus di Dealer Tatarunggul Santosa Lodoyo Kecamatan Sutojayan).

\section{Pengaruh Pemasaran terhadap Keputusan Pembelian pada PT Mulya Krida Resik}


Hasil pengujian hipotesis secara parsial terdapat pengaruh positif dan signifikan antara Pemasaran terhadap Keputusan Pembelian pada PT Mulya Krida Resik.

Hasil Penelitian ini sejalan dengan penelitian yang dilakukan oleh Kamsiani (2017) dengan judul penelitian Pengaruh Bauran Pemasaran terhadap Keputusan Mengunakan Jasa pada CV Nirwana Printing di Samarinda. Dapat disimpulkan berdasarkan analisis data, Secara simultan ditunjukkan bahwa variabel produk, harga, tempat, promosi, orang, proses, dan bukti fisik secara bersama-sama berpengaruh terhadap keputusan menggunakan jasa pada CV Nirwana Printing di Samarinda. Ini berarti hipotesis diterima. Hal ini menunjukkan bahwa secara bersama-sama tujuh variabel ini turut berpengaruh terhadap keputusan menggunakan jasa. Sedangkan secara parsial ditunjukkan bahwa variabel produk dan bukti fisik yaitu yang sigfnifikan mempengaruhi keputusan menggunakan jasa pada CV Nirwana Printing di Samarinda sedangkan variabel tempat, harga, promosi, orang dan proses tidak mempengaruhi keputusan menggunakan jasa pada CV Nirwana Printing di Samarinda.

Pengaruh Perilaku Usaha dan Pemasaran terhadap Keputusan Pembelian pada PT Mulya Krida Resik

Hasil pengujian hipotesis secara simultan diperoleh secara simultan terdapat pengaruh positif dan signifikan antara Perilaku Usaha dan Pemasaran terhadap Keputusan Pembelian pada PT Mulya Krida Resik.

Hasil Penelitian ini sejalan dengan penelitian yang dilakukan oleh Novia (2018) dengan judul penelitian Faktor yang Mempengaruhi Perilaku Usaha dalam Keputusan Pembeliana Komputer di Universitas Hasannudin. Hasil penelitian menunjukkan bahwa Faktor internal dan eksternal berpengaruh positif dan signifikan terhadap keputusan pembelian.

Hasil Penelitian ini sejalan dengan penelitian yang dilakukan oleh Agus Widarko (2018) dengan judul penelitian Pengaruh Pemasaran Online terhadap Keputusan Pembelian Konsumen (Studi kasus pada konsumen Toko Sinar Muda Busa). Hasil penelitian menunjukkan bahwa Pemasaran Online berpengaruh positif dan signifikan terhadap Keputusan Pembelian Konsumen (Studi kasus pada konsumen Toko Sinar Muda Busa).

\section{SIMPULAN DAN REKOMENDASI}

\section{Kesimpulan}

Berdasarkan dari hasil penelitian dan pembahasan, maka dapat disimpulkan bahwa:

1. Hasil penelitian menyatakan pengaruh Perilaku Usaha dan Pemasaran tehadap Keputusan Pembelian yang ditunjukkan dari hasil analisis regresi linear berganda memberikan arti bahwa setiap peningkatan aspek pada variabel Perilaku Usaha dan Pemasaran sebesar satu-satuan maka Keputusan Pembelian pada PT Mulya Krida Resik akan meningkat.

2. Hasil pengujian hipotesis terdapat pengaruh positif dan signifikan antara Perilaku Usaha terhadap Keputusan Pembelian pada PT Mulya Krida Resik.

3. Hasil pengujian hipotesis terdapat pengaruh positif dan signifikan antara Pemasaran terhadap Keputusan Pembelian pada PT Mulya Krida Resik.

4. Hasil pengujian hipotesis terdapat pengaruh positif dan signifikan antara Perilaku Usaha dan Pemasaran terhadap Keputusan Pembelian pada PT Mulya Krida Resik.

5. Untuk koefisien determinasi Perilaku Usaha dan Pemasaran menjelaskan keterkaitan 
dengan Keputusan Pembelian pada PT Mulya Krida Resik.

\section{Implikasi Manajerial}

Adapun saran dalam penelitian ini yakni :

1. PT Mulya Krida Resik meningkatkan keputusan pembelian dengan cara memperbaiki Perilaku Usaha yaitu:

a. PT Mulya Krida Resik dapat mempertahankan agar pelanggan tetap percaya kepada perusahaan hal ini dengan selalu memberikan informasi kepada pelanggan yang benar dan sesuai dengan kenyataan yang ada. Informasi juga dapat disampaikan lewat email.

b. PT Mulya Krida Resik meningkatkan dengan memahami kebutuhan pelanggan dengan cara memberikan potongan harga yang lebih besar untuk pelanggan yang membeli tinta dalam jumlah yang banyak. Pemberian paket pembelian sehingga selain meningkatkan penjualan perusahaan loyal kepada perusahaan.

2. PT Mulya Krida Resik meningkatkan keputusan pembelian dengan cara memperbaiki Pemasaran yaitu:

a. PT Mulya Krida Resik harus mempertahankan adanya pemberian potongan harga yang ada kepada pelanggan hal ini disebabkan pelanggan menyukai adanya pemotongan harga yang diberikan.

b. Program promosi yang dirancang harus dapat meningkatkan penjualan dapat dilakukan dengan pemberian hadiah kepada pelanggan yang loyal dan selalu membeli dalam jumlah yang banyak. Pemberian hadiah berupa smartphone.

\section{Saran Akademis}

Saran-saran akademis yang dapat diberikan adalah:

1. Manambah Variabel Penelitian

Bagi peneliti selanjutnya yang ingin meneliti atau melanjutkan penelitian ini, disarankan untuk dapat meneruskan penelitian ini dengan mencari variabel-variabel lain yang dapat mempengaruhi peningkatan dan perbaikan keputusan pembelian tinta dengan melakukan penelitian selain perilaku usaha dan pemasaran seperti promosi, kualitas produk, inovasi produk.

2. Menambah Jumlah Responden.

Sehubungan keterbatasan waktu, tenaga dan biaya, penelitian ini hanya mengambil 122 responden sebagai sampel. Untuk penelitian selanjutnya diharapkan untuk meningkatkan jumlah responden yang diteliti agar lebih memperoleh infromasi yang lengkap.

3. Perluasan Geografis.

Salah satu keterbatasan dalam penelitian ini adalah responden yang kurang beragam karena sampel hanya diambil dari satu tempat saja yaitu di PT Mulya Krida Resik. Bagi peneliti selanjutnya diharapkan mampu memperluas area penelitian. 


\section{DAFTAR PUSTAKA}

Abdurrahman, Herdiana, Nana. 2015. Manajemen Strategi Pemasaran. Bandung : Pustaka Setia.

Assauri, Sofjan. 2014. Manajemen Pemasaran. Jakarta : Rajawali Pers.

Darmanto. 2019. Manajemen Pemasaran. Jakarta: PT. Rajagrafindo Persada.

Firmansyah, Anang. 2019. Perilaku Konsumen (Sikap dan Pemasaran). Penerbit Deepunlish, Yogyakarta.

Hasan, Ali. 2013. Marketing dan Kasus-kasus Pilihan. Cetakan Kesatu. Penerbit CAPS (Center for Academic Publishing Service), Yogyakarta.

Manap, Abdul. 2016. Revolusi Manajemen Pemasaran. Edisi Pertama. Penerbit Mitra. Wacana Media, Jakarta.

Nitisusastro, Mulyadi. 2013. Perilaku Konsumen dalam Perspektif Kewirausahaan. Bandung : Alfabeta.

Sanusi. 2014. Bauran Pemasaran dan Loyalitas Konsumen. Bandung : Alfabeta.

Setiadi, Nugroho. 2010. Perilaku Konsumen Konsep dan Implikasi untuk Strategi dan Penelitian Pemasaran. Jakarta: Kencana

Simamora, Bilson. 2013. Memenangkan Pasar dengan Pemasaran Efektif dan Profitabel. Jakarta: PT. Gramedia Pustaka Utama.

Sudomo. 2013. Marketing dan Kasus-kasus Pilihan. Cetakan Kesatu. Yogyakarta : CAPS (Center for Academic Publishing Service).

Sunyoto, Danang. 2014. Teori, Kuesioner dan Analisa Data. Cetakan Kesatu. Yogyakarta : Center for Academic Publishing Service.

Yanti, Arifah. 2015. Faktor-faktor yang Mempengaruhi Perilaku Wirausaha Mompreneur (Studi Kasus : Komunitas Bunda Online. Forum Agribisnis no.1 Vol.8.

Yuyus, Suryana. 2014. Keriwausahan Pendekatan Karakteristik Wirausaha Sukes. Penerbit Deepunlish, Yogyakarta. 